\title{
Construction of an almond linkage map in an Australian population Nonpareil $\times$ Lauranne
}

\author{
Iraj Tavassolian ${ }^{1,6 \dagger}$, Gholmereza Rabiei ${ }^{2+}$, Davina Gregory ${ }^{1,7}$, Mourad Mnejja ${ }^{3}$, Michelle G Wirthensohn', \\ Peter W Hunt ${ }^{4}$, John P Gibson ${ }^{2}$, Christopher M Ford ${ }^{1}$, Margaret Sedgley ${ }^{5}$, Shu-Biao Wu ${ }^{2 *}$
}

\begin{abstract}
Background: Despite a high genetic similarity to peach, almonds (Prunus dulcis) have a fleshless fruit and edible kernel, produced as a crop for human consumption. While the release of peach genome v1.0 provides an excellent opportunity for almond genetic and genomic studies, well-assessed segregating populations and the respective saturated genetic linkage maps lay the foundation for such studies to be completed in almond.

Results: Using an almond intraspecific cross between 'Nonpareil' and 'Lauranne' ( $\mathrm{N} \times \mathrm{L})$, we constructed a moderately saturated map with SSRs, SNPs, ISSRs and RAPDs. The $N \times L$ map covered $591.4 \mathrm{cM}$ of the genome with 157 loci. The average marker distance of the map was $4.0 \mathrm{cM}$. The map displayed high synteny and colinearity with the Prunus $T \times E$ reference map in all eight linkage groups (G1-G8). The positions of 14 mapped gene-anchored SNPs corresponded approximately with the positions of homologous sequences in the peach genome v1.0. Analysis of Mendelian segregation ratios showed that $17.9 \%$ of markers had significantly skewed genotype ratios at the level of $P<0.05$. Due to the large number of skewed markers in the linkage group 7 , the potential existence of deleterious gene(s) was assessed in the group. Integrated maps produced by two different mapping methods using JoinMap ${ }^{\circledast} 3$ were compared, and their high degree of similarity was evident despite the positional inconsistency of a few markers.
\end{abstract}

Conclusions: We presented a moderately saturated Australian almond map, which is highly syntenic and collinear with the Prunus reference map and peach genome V1.0. Therefore, the well-assessed almond population reported here can be used to investigate the traits of interest under Australian growing conditions, and provides more information on the almond genome for the international community.

\section{Background}

Almond (Prunus dulcis (Mill) D. A. Webb) is an ancient plant species domesticated by humans initially in the Middle East. P. fenzliana or P. communis have been considered its most likely wild ancestors $[1,2]$. Valued for its health benefits and high nutritional value, the importance of the crop is increasing in the human diet, and consequently its production and commercial value are growing worldwide. Despite a high genetic similarity to peach, almonds have a fleshless fruit and edible kernel, rather than an edible fruit. Many agronomic traits important to almond such as shell hardness, kernel

\footnotetext{
* Correspondence: shubiao.wu@une.edu.au

+ Contributed equally

${ }^{2}$ Centre for Genetic Analysis and Applications and School of Environmental and Rural Science, University of New England, Armidale, NSW 2351, Australia Full list of author information is available at the end of the article
}

taste, kernel weight, resistance to biotic/abiotic stress, blooming time and self-incompatibility have been investigated, and efforts towards mapping and molecular characterisation of these genes have been made [3-13]. With the aid of the peach genome sequence released recently [14], characterisation of the almond genes responsible for agronomically important traits will become easier. However, well-assessed almond mapping populations and subsequent genetic maps are still fundamental for investigations of the genetic and molecular control of important traits.

A saturated linkage map can be a useful tool in the study of plant genetics and breeding. Close associations between important traits and molecular markers can assist fast selection of plants with desired features at early stages of growth. This is particularly valuable for breeding programs of woody plants because conventional, phenotype-based 
selection in these is delayed due to a long juvenile stage. Arùs et al. (1994) first reported a linkage map in a 'Ferragnes' $\times$ 'Tuono' $(\mathrm{F} \times \mathrm{T})$ almond population with RFLP and isozyme markers, where the map distance was omitted [15]. Later the density and coverage of the map was improved by the addition of more markers [16,17]. Ballester (1998) constructed a molecular genetic map of a cross 'Felisia' × 'Bertina' $(\mathrm{F} \times \mathrm{B})$ [18], and later a Late bloom gene was mapped in the population [13]. Sánchez-Pérez et al. (2007) mapped 11 traits (genes or QTL) in a cross of 'R1000' × 'Desmayo Largueta' (RxD) with 56 SSRs in the map [4]. However, more mapping populations and saturated maps are required to assist broader assessment of the almond traits and gene discovery especially under different environments and management systems. In Australia, a genetic linkage mapping program was initiated by Gregory [19] in a 'Nonpareil' $\times$ 'Lauranne' cross $(\mathrm{N} \times \mathrm{L})$, but the integrated map with mainly RAPDs and ISSRs was sparse and further saturation was desirable [20]. Recently, Wu et al. (2009) reported that 12 SNP-anchored genes were mapped on six linkage groups in the same population with a higher map density [21]. Genetic maps have also been constructed in crosses between almond and peach including 'Texas'x'Earlygold' $(\mathrm{T} \times \mathrm{E}$ ) [22-24], 'Garfi'x'Nemared' (GxN) [25], 'Padre' × '54P455' (Px5) [26,27] and a derivative population from GxN [28]. The most important map is the $\mathrm{T} \times \mathrm{E}$ map that has been generally accepted as a marker-saturated Prunus reference map. This map has been used to position genes corresponding to 1236 ESTs [29], locate 42 putative resistance regions [30], and align 613 rosaceaous unigenes that correspond to single copy Arabidopsis genes [31]: the Rosaceae Conserved Orthologous Set (RosCOS) map. A number of QTL have also been mapped using the $\mathrm{T} \times \mathrm{E}$ map [11].

In this study, we developed a moderately saturated linkage map by adding SSRs and SNPs to the $\mathrm{N} \times \mathrm{L}$ F1 map constructed by Gregory et al. (2005) [20]. The map was compared with the Prunus $\mathrm{T} \times \mathrm{E}$ reference map to demonstrate high synteny and colinearity between the $\mathrm{N}$ $\times \mathrm{L}$ and the reference map. The sequences of the geneanchored SNPs $[21,32,33]$ were also compared to the peach genome v1.0 and the mapped positions generally agreed with the peach genome positions. The $\mathrm{N} \times \mathrm{L}$ genetic map reported here can be used to investigate traits of interest under the Southern Australian winter rainfall inland environment, and provides more almond genome information for the international community.

\section{Results}

\section{Marker polymorphism}

Altogether, 179 markers were polymorphic in the population under analysis. Of these, 92 (51.4\%) were heterozygous in both parents, 34 with 4 alleles, 37 with 3 alleles, and 21 with 2 alleles; 40 (22.3\%) were heterozygous only in Nonpareil; and 47 (26.3\%) were heterozygous only in Lauranne. SSR markers BPРCT009, CPDCT020, CPSCT039 and UDAp-479 demonstrated multi-locus amplifications, each with two loci, across the population. The mapping results (see following description) indicated, however, that the loci of BPPCT009 were located closely in the same linkage group at a distance of $6.0 \mathrm{cM}$.

\section{Segregation of the markers}

Of 179 markers analysed, 147 (82.1\%) segregated in the expected Mendelian segregation ratios, and 32 (17.9\%) showed skewed segregations $(\mathrm{P}<0.05)$, with $19 / 113$ (16.8\%) SSR, 6/34 (17.6\%) ISSR, 5/14 (35.7\%) RAPD, and $2 / 14$ (14.3\%) SNP markers showing skewed ratios. Following grouping of the markers in the mapping process, $10 / 20(50.0 \%)$ of the markers appearing in linkage group 7 (G7) had skewed segregation ratios, which was extremely high compared to the average across other groups $22 / 159(13.8 \%)$. Interestingly, the only two skewed SNP markers were grouped in G7. To avoid using too few markers for a framework construction, all the skewed markers in G7 were included in the first step of mapping, and second step mapping for this group was omitted.

A plot of negative $\log _{10}$ of $p$-values $\left[-\log _{10}(p)\right]$ in $\chi^{2}$ tests comparing frequencies of alleles of the loci in the G7 versus their map positions is shown in Figure 1. A main peak was identified in the area between markers CPРCT007 and N-93. While a few markers with low $-\log _{10}(\mathrm{P})$ values were present in the adjacent areas of the peak, a trend that the $-\log _{10}(\mathrm{P})$ values declined gradually towards two ends of the linkage group was clearly illustrated.

\section{Linkage maps constructed using One-step and Two-step methods}

A final linkage map of $591.4 \mathrm{cM}$ containing 157 markers (93 SSRs, 35 ISSRs, 14 SNPs, 4 -alleles, and 11 RAPDs) was constructed using the One-step method of JoinMap ${ }^{\circ}$ (Table 1). The average marker distance of the map was $4.0 \mathrm{cM}$, and 27 skewed markers were mapped in the genome of the population. Individually, G1 was the longest group covering $108.2 \mathrm{cM}$ with 22 markers. G5 was the shortest group covering $54.8 \mathrm{cM}$ with 17 markers. The average marker distance varied from 2.4 (G6) to 5.7 (G8) cM. As indicated previously, G7 mapped the highest number of segregation ratio skewed markers (10), whereas G5 had no skewed markers in the group.

Using the Two-step method, the final map was 603.9 cM contained 160 markers (95 SSRs, 35 ISSRs, 18 SNPs/INDELS, and 12 RAPDs) (Table 1). The average marker distance of this map was $4.0 \mathrm{cM}$ and 28 skewed markers were included in the map. Similar to the Onestep map, G1 was the longest group at $113 \mathrm{cM}$ 


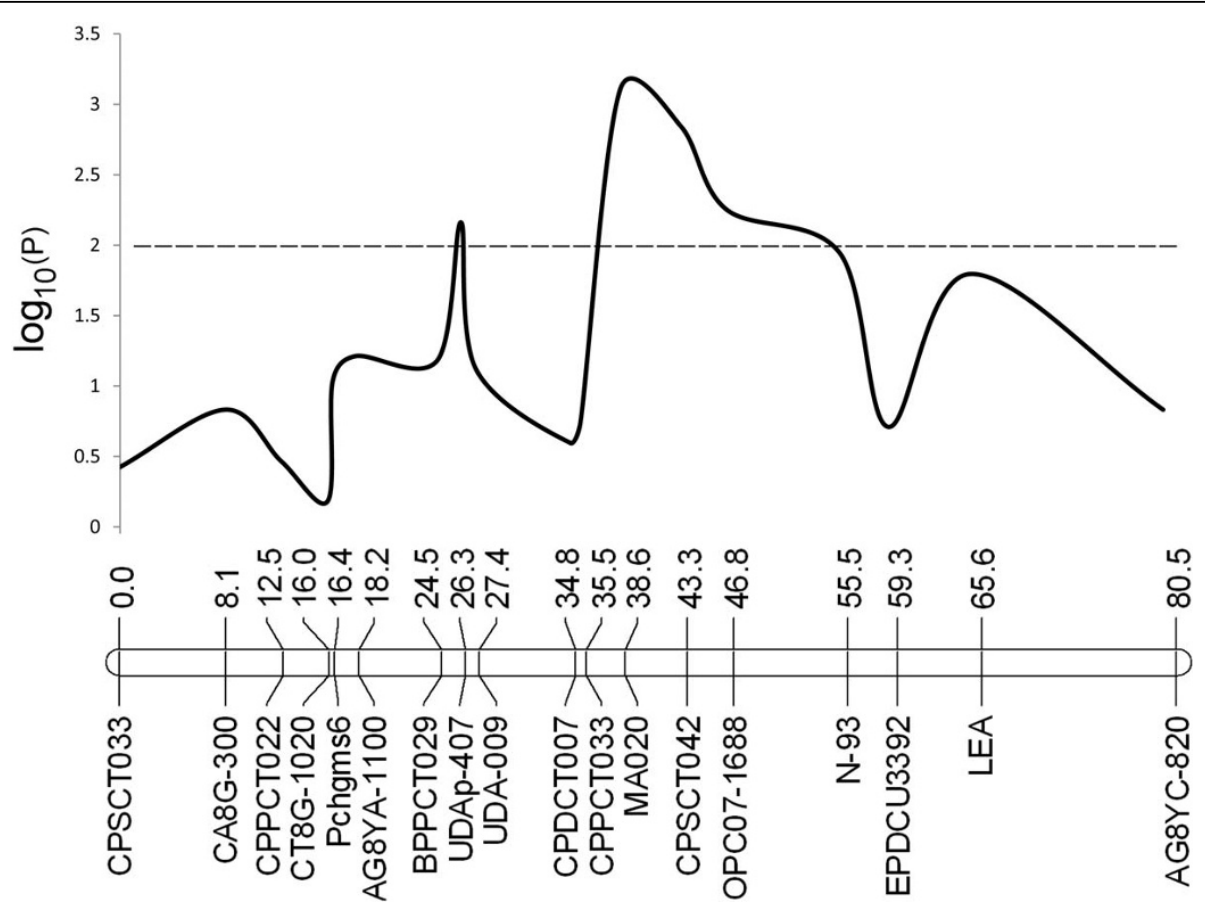

Figure $1 \mathrm{~A}$ plot of negative $\log _{10}$ of $p$-values $\left[-\log _{10}(p)\right]$ in $\chi^{2}$ tests comparing frequencies of alleles of the loci in the G7 versus their map positions resulting from the One-step mapping method. A main peak was shown in the area between markers CPPCT007 and N-93. A higher $-\log _{10}(p)$ demonstrates the higher deviation of genotype segregation of a locus from the expected Mendelian ratio. Horizontal broken line shows threshold of statistical significance $[-\log 10(p)=2$, corresponding to $p=0.01]$.

containing 24 markers. G5 was the shortest group at $54.4 \mathrm{cM}$ containing 17 markers. The average marker distance varied from 2.7 (G6) to 5.5 (G8). As with the One-step method, G7 had the highest number of skewed markers (10) whereas G5 had no skewed markers mapped.

For most of the markers, the two methods produced consistent mapping results as shown in Figure 2. The linkage groups G5 and G7 produced by the One-step and Two-step methods were completely collinear with no rearranged linkage order. Other linkage groups had one or more markers in different map order in the two maps. Although the divergence in positions were not substantial for most markers, seven markers showed shifts larger than $20 \mathrm{cM}$, i.e., CT8G-743 in G1, UDA008 and AG8YC-714 in G2, CPDCT008 in G3, AG8YC771 in G6 and AG8YA-763 and OPA08-1175 in G8 with shifts of: $48.9 \mathrm{cM}, 30.4 \mathrm{cM}, 20.1 \mathrm{cM}, 41.6 \mathrm{cM}, 25.2$ cM, $61.8 \mathrm{cM}$, and $29.5 \mathrm{cM}$ respectively. Among these, CT8G-743, CPDCT008, AG8YC-771 and AG8YA-763 showed significantly skewed segregation ratios, and most (5/7) were dominant markers (ISSR and RAPD). The

Table 1 Statistics of the maps constructed using One-step and Two-step methods

\begin{tabular}{|c|c|c|c|c|c|c|c|c|}
\hline \multicolumn{5}{|c|}{ One-step } & \multicolumn{4}{|c|}{ Two-step } \\
\hline Group & $\begin{array}{l}\text { Number } \\
\text { of loci }\end{array}$ & $\begin{array}{l}\text { Size } \\
\text { (cM) }\end{array}$ & $\begin{array}{l}\text { Average marker } \\
\text { distance (cM) }\end{array}$ & $\begin{array}{c}\text { Number of skewed } \\
\text { markers }\end{array}$ & $\begin{array}{l}\text { Number } \\
\text { of loci }\end{array}$ & $\begin{array}{l}\text { Size } \\
\text { (cM) }\end{array}$ & $\begin{array}{l}\text { Average marker } \\
\text { distance (cM) }\end{array}$ & $\begin{array}{c}\text { Number of skewed } \\
\text { markers }\end{array}$ \\
\hline G1 & 22 & 108.2 & 5.2 & 3 & 24 & 113.0 & 4.9 & 3 \\
\hline G2 & 16 & 56.0 & 3.7 & 1 & 16 & 48.4 & 3.2 & 1 \\
\hline G3 & 21 & 69.4 & 3.5 & 5 & 21 & 72.3 & 3.6 & 6 \\
\hline G4 & 21 & 83.6 & 4.2 & 3 & 21 & 89.4 & 4.5 & 3 \\
\hline G5 & 17 & 54.8 & 3.4 & 0 & 17 & 54.4 & 3.4 & 0 \\
\hline G6 & 28 & 65.0 & 2.4 & 2 & 28 & 72.8 & 2.7 & 2 \\
\hline G7 & 18 & 80.5 & 4.7 & 10 & 18 & 81.6 & 4.8 & 10 \\
\hline G8 & 14 & 73.9 & 5.7 & 3 & 15 & 76.5 & 5.5 & 3 \\
\hline $\begin{array}{l}\text { Total/ } \\
\text { average }\end{array}$ & 157 & 591.4 & 4.0 & 27 & 160 & 603.9 & 4.0 & 28 \\
\hline
\end{tabular}




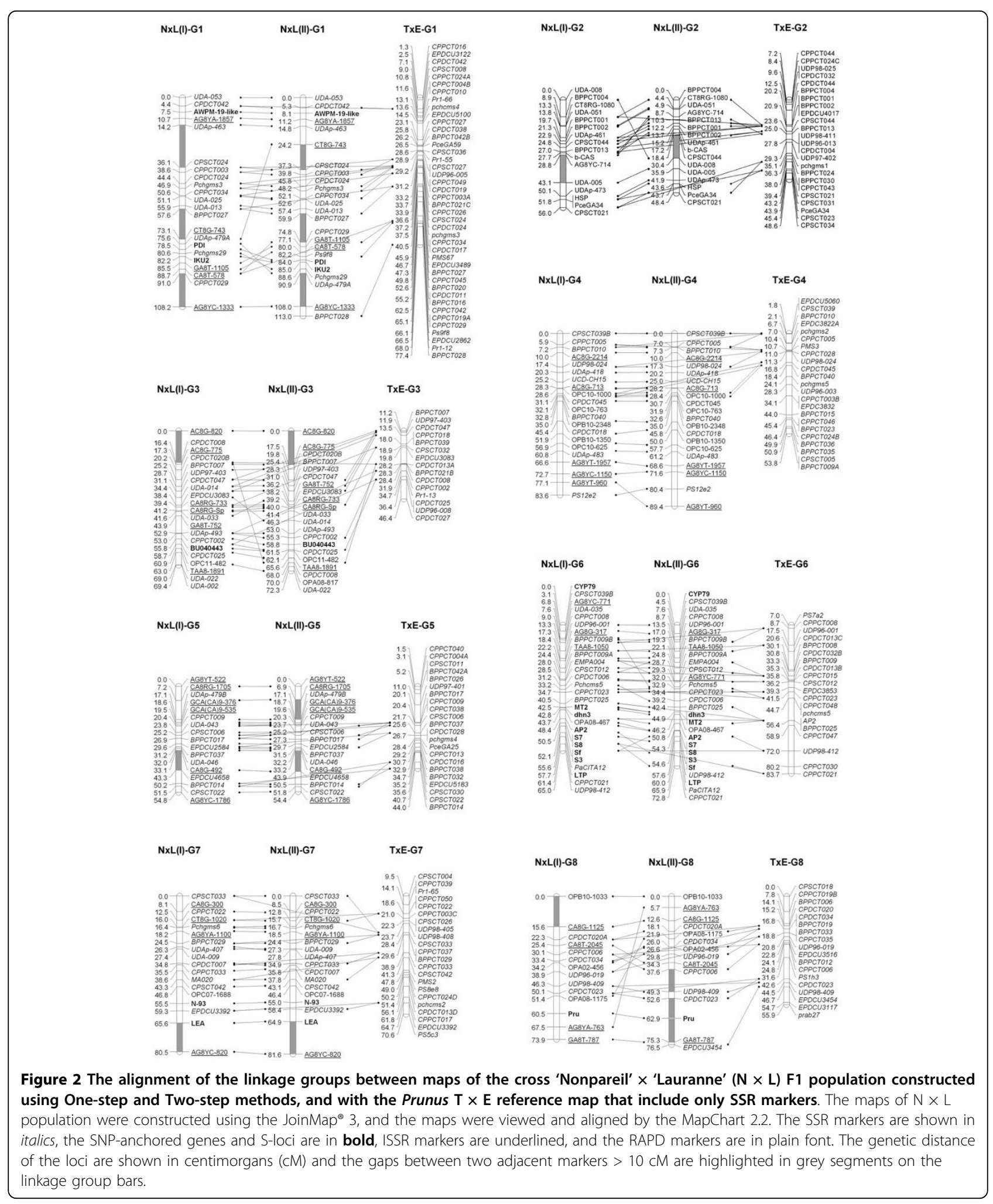


segment from marker UDAp-479A to marker CPPCT029 of G1 (in map I) and from marker CA8T2045 to marker UDP96-019 of G8 (in map I) was inverted between the two maps.

Among the markers mapped in the $\mathrm{N} \times \mathrm{L}$ population, the ISSRs were developed in our initial analysis, and therefore were newly mapped markers in the $P$. dulcis map. The SSRs were identified from published studies, and the majority of the markers mapped in the same linkage groups as previously reported. However, a few SSR markers were mapped for the first time: CPDCT018 on G4, CPDCT006 on G6, and CPDCT007 on G7. Moreover, some markers amplified more loci in the $\mathrm{N} \times \mathrm{L}$ population than in the previous report or mapped to different linkage groups. CPDCT020 mapped to G8 in the $\mathrm{T} \times \mathrm{E}$ reference map [23] and the "Contender" $\times$ "Fla.92-2C" peach map [34] as a single locus marker. The primers for this marker amplified two loci in the $\mathrm{N} \times \mathrm{L}$ population, which mapped to G3 and G8. Primers for UDAp-479 also amplified two loci, which mapped to G1 and G5 in our study. A recent report identified four loci for UDA-479 in the apricot population "Z506-07" $(\mathrm{Z}) \times$ "Currot" $(\mathrm{C})$ and all four loci were assigned to G8 [35]. Two loci of BРPCT009 were mapped to G4 of the peach "Ferjalou Jalousia" $\times$ "Fantasia" [36] and T $\times$ E reference maps [23] for locus A, and G7 of the "Ferjalou Jalousia" $\times$ "Fantasia" map [36] and G6 of the $\mathrm{T} \times \mathrm{E}$ reference map [23] for locus B. In contrast, two loci for BРPCT009 were mapped to G6 of our mapping population in an interval of $6.0 \mathrm{cM}$.

In the maps constructed by both methods, gaps bigger than $10 \mathrm{cM}$ were observed (segments in grey shown in Figure 2). These included one gap on G2, G3, G5, G7 and G8, and three gaps on G1 in the One-step map, and one gap on G2, G3, and G7, two gaps on G5, and three gaps on G1 and G8 in the Two-step map. The Two-step map had more gaps (11) of $>10 \mathrm{cM}$ than the One-step map (8). The biggest gap $(21.9 \mathrm{cM})$ was between the markers UDAp-463 and CPSCT024 on G1 of the One-step map.

\section{Synteny of the $N \times L$ and $T \times E$ maps and between the almond and peach genomes}

The almond $\mathrm{N} \times \mathrm{L}$ and Prunus $\mathrm{T} \times \mathrm{E}$ reference genetic maps were compared using common SSR markers to visualise the syntenic regions. As shown in Figure 2, a high degree of macro-synteny between $\mathrm{N} \times \mathrm{L}$ and $\mathrm{T} \times \mathrm{E}$ was evident across the whole genome with 59 common SSR markers. For example, the linkage groups G1, G4 and G6 did not show any order conflict between the $\mathrm{N}$ $\times \mathrm{L}$ and $\mathrm{T} \times \mathrm{E}$ maps. Despite the high degree of macrosynteny, rearrangements of markers in small sections occurred in the other linkage groups. Furthermore, a few markers showed inconsistency of position over larger distances between the $\mathrm{N} \times \mathrm{L}$ and $\mathrm{T} \times \mathrm{E}$ maps. For instance, the marker CPSCT033 mapped to the top of G5 in the $\mathrm{N} \times \mathrm{L}$ maps (I and II), while it was located in the middle segment of $\mathrm{T} \times \mathrm{E} 28.4 \mathrm{cM}$ from the top. The marker CPDCT008 was mapped to the upper part $(\mathrm{N} \times \mathrm{L}$ map I) or the lower part $(\mathrm{N} \times \mathrm{L}$ map II $)$ of $\mathrm{G} 3$ but to the lower middle part in $\mathrm{T} \times \mathrm{E}$. With reference to the $\mathrm{T} \times \mathrm{E}$ map, the $\mathrm{N} \times \mathrm{L}$ map coverage of the genome varied with linkage groups. G1 and G6 covered the whole length of the corresponding groups of $T \times E ; G 2$, G3, and G7 covered most of their corresponding groups with one end or both ends having no common markers with $\mathrm{T} \times \mathrm{E}$ but covering equivalent lengths; G4 and G5 had fewer markers in common with the $\mathrm{T} \times \mathrm{E}$ map but comparison with maps in the GDR database http:// www.rosaceae.org[37] indicated full coverage of G4; and G8 alignment indicated that at least the bottom part of approximately $10 \mathrm{cM}$ was not mapped in $\mathrm{N} \times \mathrm{L}$. Hence, this $\mathrm{N} \times \mathrm{L}$ map can be regarded as moderately saturated.

The sequences of fourteen SNP-anchored genes were compared using Blastn with the peach genome v1.0 database, and homologous sequences were located in the scaffolds of the peach genome. As the scaffolds correspond to each of the linkage groups of Prunus maps, the relative positions of the genes can be identified in the genome. The results showed that the locations of the majority of the genes mapped in the $\mathrm{N} \times \mathrm{L}$ population agreed with the positions of their homologous sequences in the corresponding peach genome scaffolds (Figure 3). AWPM-19-like, however, was located near the top of G1 rather than in the lower middle part of the group, where the homologous sequence was identified in the peach genome scaffold_1. In G6, the segment involving MT2, dhn3 and AP2 showed inversion compared to the peach genome despite spanning only a small fragment with genetic distance of $5.9 \mathrm{cM}$ or DNA length of $2.6 \mathrm{Mbp}$.

\section{Discussion}

In this study, we constructed almond linkage maps of an Australia population derived from the cross between the American cultivar 'Nonpareil' as maternal parent and the French cultivar 'Lauranne' as pollen donor $(\mathrm{N} \times \mathrm{L})$. Two maps were constructed using One-step and Two-step methods, with total lengths of $591.4 \mathrm{cM}$ and $603.9 \mathrm{cM}$ respectively. 157 molecular markers were positioned on the One-step and 160 markers were positioned on the Two-step map. The resulting maps showed high colinearity with the Prunus $\mathrm{T} \times \mathrm{E}$ reference map $[24,36]$.

To obtain an integrated map of a cross pollinated population, individual parental maps were generally constructed and then integrated to produce a consensus 


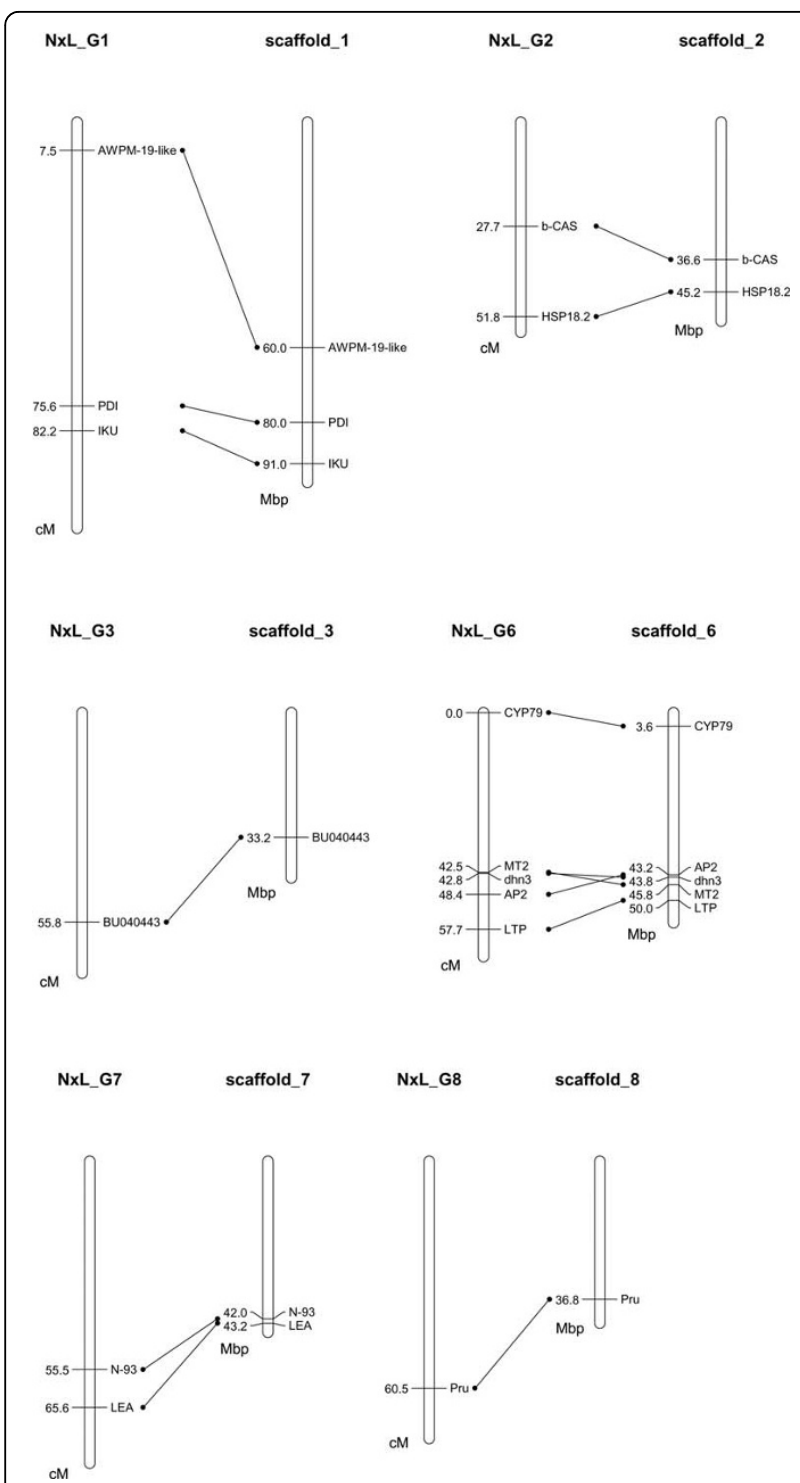

Figure 3 Comparison of the positions of SNP-anchored genes mapped in the $\mathrm{N} \times \mathrm{L}$ population (map I) with the positions of their homologous sequences in the scaffolds of peach genome v1.0. The genetic distance in the $N \times L$ map is shown in centimorgans (cM), and the positions of the homologous sequences in the scaffolds of peach genome $v 1.0$ are shown in mega basepairs (M). The scaffold bars represent the whole length of the corresponding chromosomal DNA. The locations of all the genes except AWPM-19-like mapped in the $N \times L$ population agreed with the positions of their homologous sequences in corresponding peach genome scaffolds. AWPM-19-like gene positioned near the top of $N \times L G 1$, but in the lower part of the peach genome scaffold_1. An inversion is present in the segment including genes MT2, dhn3, and AP2.

map of the population by estimation of the average recombination frequency of the loci in the two parents, as has been used for other pseudo-test cross mapping populations in many tree species [38-40]. In this study, we denoted this as the Two-step method. Since the release of
JoinMap ${ }^{\circ}$ version 3 [41], the construction of an integrated map of the population can be undertaken by loading all the genotyping data of the population, bypassing individual parental map construction in a One-step strategy. Genetic maps constructed in this way have been published in recent years [42-44]. During initial mapping analysis, we tried both the One-step and Two-step methods, and variations of marker distances and positions were identified. As the comparison studies had not been reported, we applied both methods in our $\mathrm{N} \times \mathrm{L}$ almond population to investigate whether different methods yield significantly different maps. Based on our study, these two integration methods did not result in substantial differences for all the linkage groups, and only a small proportion of markers showed positional instability between the two maps. The majority of the markers (6/7) that had a position shift of greater than $20 \mathrm{cM}$ between two maps showed skewed segregation ratios or were adjacent to markers with skewed segregation. The fewer large gaps generated in the One-step map suggest that the One-step mapping is an appropriate method to construct an integrated map of a pseudo-test cross population such as in the almond and other tree plants. Therefore, in this study, the One-step map was used to represent the $\mathrm{N} \times \mathrm{L}$ genome for other analyses (Figures 1 and 3).

Linkage maps based on intraspecific crosses of almond have been reported for the crosses of 'Ferragnes' $x$ 'Tuono' $(\mathrm{F} \times \mathrm{T})$ [15-17], 'Felisia' $\times$ 'Bertina' $(\mathrm{F} \times \mathrm{B})$ [13,18], 'R1000' $\times$ 'Desmayo Largueta' (RxD) [4], and 'Nonpareil $\times$ Lauranne' $(\mathrm{N} \times \mathrm{L})[20,21]$. While $\mathrm{F} \times \mathrm{T}$ and $\mathrm{F} \times \mathrm{B}$ maps consisted mostly of RFLP and RAPD markers, the RxD map contains 56 SSR markers with less density across the genome. SSRs are the favoured marker type used for many applications in plant genetics including genetic mapping because of easy transferability between intraspecific populations and across closely related species, and a high number of alleles per locus that provides greater information content [45-48]. Therefore, a saturated map containing additional SSR markers is warranted in almond intraspecific crosses. The $\mathrm{N} \times \mathrm{L}$ map was initiated with RAPDs, ISSRs and the small numbers of SSR, and a sparse integrated map was subsequently produced [20]. Using high resolution melting curve analysis [32], Wu et al. mapped 12 geneanchored SNPs on six linkage groups plus the addition of more SSR to the map [21]. In the present study, we have constructed a combined molecular linkage map including SSR, SNP, RAPD, and ISSR markers. In comparison with the Prunus $\mathrm{T} \times \mathrm{E}$ reference map and other maps reported in Prunus (data not shown), the linkage groups of the $\mathrm{N} \times \mathrm{L}$ map covered close to the whole length of the almond linkage groups with the exception of G8 which requires further extension beyond EPDCU3454. With reasonable dense coverage of the 
genome by SSRs and SNPs, the map can readily be used in the Australian almond breeding program [49] and contribute to international almond genome research.

The clustering of loci with skewed segregation ratios on G7 suggests a possible association of deleterious genes with this section of the linkage group and a more in depth study to investigate this possibility is warranted. In a peach F2 mapping population, no linkage of markers could be established for G7 [50] possibly due to the complexity of marker segregation. In our study, more than half $(10 / 18)$ of the mapped markers had significantly skewed segregation ratios, and most of the skewed markers clustered on the central section of the linkage group with a peak of segregation distortion around marker MA020. This finding indicates that the area may harbour one or more deleterious genes. Although some genes or traits related to biotic or abiotic stress have been mapped to this group such as the nematode resistance trait MA [30] and the DHN gene involved in freezing and drought tolerance [27], those genes were probably not the cause of the distorted segregations as these occur in a different region of G7. It would be interesting to search for deleterious gene alleles in the region around MA020. The recent release of peach genome v1.0 provides a good opportunity for conducting such investigations.

With the release of $a>7$ fold coverage peach genome in April 2010 (v1.0), with 27,852 genes predicted [14], genomic exploration in Prunus and more widely in the family Rosaceae and perhaps other tree plants will accelerate. In the present study, we compared 14 SNPanchored genes mapped in the $\mathrm{N} \times \mathrm{L}$ population with the peach genome v1.0. A high synteny between our map and the peach genome was observed as expected. However, an inversion was noted in a G6 segment including genes MT2, dhn3, and AP2. The evidence for the inversion will become clearer when the almond genome is sequenced and a final sequence build is achieved in the future. Nevertheless, as the closest relative of peach, genetic and genomic studies in almond will benefit significantly from the publication of the peach genome sequences prior to the complete sequencing of the almond genome. For almond researchers and breeders to fully utilise the sequence information becoming available for peach, well-assessed almond populations and genetic maps are required to associate important agronomic traits of the species with predicted genes in peach. Development of saturated genetic marker maps such as that presented in this paper will be valuable for almond genetic research and breeding programs.

\section{Conclusions}

Here, we presented a moderately saturated Australian almond map, which is highly syntenic and collinear with the Prunus T $\times$ E reference map and peach genome V1.0. It was identified that a section of G7 with skewed markers may harbour one or more deleterious gene(s), and further investigation to search for such a gene is suggested. The comparison of One-step and Two-step methods indicated that these two methods produced highly consistent maps, but Onestep method was a preferred mapping approach. The well-assessed almond population reported here can be used to investigate the traits of interest under Australian growing conditions, and provides more information on the almond genome for the international community.

\section{Methods}

\section{Mapping population and DNA extraction}

An almond pseudo-testcross population with 93 progeny, derived from the cross between the American cultivar 'Nonpareil' as maternal parent and the French cultivar 'Lauranne' as pollen donor, was used as the mapping population $(\mathrm{N} \times \mathrm{L})$ [21]. The population was planted in a commercial orchard at Lindsay Point - Victoria, Australia $\left(34^{\circ} 15^{\prime} 27^{\prime \prime} \mathrm{S}-141^{\circ} 00^{\prime} 00^{\prime \prime} \mathrm{E}\right)$ with a fertile and well drained soil and an average of $223 \mathrm{~mm}$ annual rainfall. Standard orchard management including fertilisation, irrigation and pruning were applied. Total genomic DNA was extracted from fresh young leaves using the protocol of Lamboy and Alpha, (1998). DNA quantity and quality was measured spectrophotometrically by Nanodrop ND-1000 (Thermo Scientific, USA).

\section{Molecular markers}

A total of 241 SSR initially reported in different Prunus species were screened for polymorphisms in the parents and selected progeny (Table 2). The designation of the markers, the original species from which the markers were developed, and the reference information are listed in Table 2. The PCR was performed in a total volume of $20 \mu$ containing $1 \times$ PCR reaction buffer (Bioline, Sydney, Australia), $2.5 \mathrm{mM} \mathrm{MgCl}_{2}, 0.2 \mathrm{mM}$ dNTPs, $0.2 \mu \mathrm{M}$ of each primer, $40 \mathrm{ng}$ of template DNA and 1 unit of Taq polymerase (Bioline, Sydney, Australia). Amplification involved first denaturation at $95^{\circ} \mathrm{C}$ for $5 \mathrm{~min}, 34$ cycles of denaturation at $95^{\circ} \mathrm{C}$ for 30 seconds, annealing at appropriate temperatures (mostly based on the information provided in the cited literature, and available on request from authors) for 30 seconds, and extension at $72^{\circ} \mathrm{C}$ for 30 seconds, and a final extension at $72^{\circ} \mathrm{C}$ for 7 min. Electrophoresis was performed on $8 \%(\mathrm{w} / \mathrm{v})$ polyacrylamide gel, or automated capillary gel on the ABI PRISM 3730 DNA Analyzer (Applied Biosystems) to visualise PCR products. Markers with good reproducibility and clearly decipherable loci were chosen for construction of linkage maps. 
Table 2 List of identifiers and numbers of the SSR markers tested, segregated and mapped

\begin{tabular}{|c|c|c|c|c|c|}
\hline Identifier & Number of markers tested & Number of markers segregated & Number of markers mapped & Species of origin & References \\
\hline AMPA & 1 & 0 & 0 & Apricot & [52] \\
\hline BPPCT & 29 & 17 & 16 & Peach & [53] \\
\hline CPDCT & 25 & 15 & 13 & Almond & {$[47]$} \\
\hline CPPCT & 25 & 13 & 12 & Peach & {$[54]$} \\
\hline CPSCT & 23 & 13 & 10 & Japanese plum & {$[55]$} \\
\hline EMPA & 3 & 1 & 1 & Sweet cherry & {$[56]$} \\
\hline EMPaS & 4 & 0 & 0 & Sweet cherry & {$[57]$} \\
\hline EPDCU & 14 & 6 & 5 & Almond & [48] \\
\hline MA & 1 & 1 & 1 & Peach & {$[58]$} \\
\hline Pac & 2 & 0 & 0 & Apricot & {$[52]$} \\
\hline $\mathrm{PaClTA}$ & 1 & 1 & 1 & Apricot & [59] \\
\hline PceGA & 3 & 1 & 1 & Sour cherry & {$[60]$} \\
\hline Pchcms & 3 & 1 & 1 & Peach & [61] \\
\hline Pchgms & 8 & 3 & 3 & Peach & {$[61,62]$} \\
\hline PMS & 3 & 0 & 0 & Peach & {$[63]$} \\
\hline PS & 4 & 2 & 2 & Sour Cherry & [16] \\
\hline UCD-CH & 8 & 2 & 1 & Sweet cherry & {$[64]$} \\
\hline UDA & 41 & 15 & 14 & Almond & {$[65]$} \\
\hline UDAp & 28 & 9 & 9 & Apricot & {$[66]$} \\
\hline UDP & 15 & 8 & 6 & Peach & {$[67]$} \\
\hline Total & 241 & 108 & 96 & & \\
\hline
\end{tabular}

The design and assay techniques for the SNPs, ISSRs and RAPDs used in the present study have been described previously [19-21,33]. The assay of self-incompatible genes $S 3, S 7$, and $S 8$, and self-fertile gene $S f$ was conducted as described by Channuntapipat [6].

\section{Map construction}

Linkage maps were constructed using JoinMap 3 software [41]. Two different mapping methods were applied and the resulting maps were compared and analysed to assess their synteny with the Prunus $\mathrm{T} \times \mathrm{E}$ reference map. The first method constructed two parental maps separately, which was followed by the production of an integrated map. As this approach involved two map construction steps [38-40], we denoted it as 'Two-step method' and the map or linkage groups labelled as "II". This included preparing two separate parental data sets as described elsewhere for a pseudo-testcross population [38]. Both sets of genotyping data were loaded into JoinMap $^{\circ} 3$ and the two parental maps were constructed separately. Chi-square analysis was performed for goodness of fit to the expected Mendelian segregation ratio for each marker and skewed markers were identified using a threshold of $\mathrm{P}<0.05$. Framework linkage groups were created by omitting the skewed markers from the data for all the linkage groups except G7, due to the high degree of skewed markers in this group (see Results section). These framework groups were used as fixed orders for the individual final map construction that included all markers. Linkage groups were established at a LOD score $>5$ and recombination fraction $<0.40$. The Kosambi mapping function was used for the calculation of map distances. Two parental maps (as frameworks or final maps) were integrated using the "Combine Groups for Map Integration" function of Joinmap 3 to produce the combined maps (framework or final maps). This method uses mean recombination frequencies and combined LOD scores for mapping calculations. The second method constructed a map by using all the markers heterozygous in both or either of the parental trees as one set of data [42-44]. As this method involved using all markers in a single map construction, it was denoted as the 'One-step method' and the map or linkage groups labelled as "I". The process of testing segregation ratios and inclusion of markers in maps was identical to that used in the 'Two-step method'. Markers in common between our maps and the Prunus $\mathrm{T} \times \mathrm{E}$ reference map were used to identify corresponding linkage groups. The resulting maps were graphically presented and their alignment was performed using Mapchart 2.2 [51].

\section{Sequence blast and localisation in Prunus genome}

Sequences of the SNP-anchored genes were blasted against peach genome v1.0 scaffolds [14], and the resulting homolog sequences were located in the scaffolds (corresponding to the linkage groups of Prunus genetic maps) using the GBrowse function http://www.rosaceae. org/gb/gbrowse/prunus_persica/. 


\section{Acknowledgements}

This research was funded by Australian Research Council Grant No. DP0556459. IT and GR were financially supported by the Ministry of Science, Research and Technology (MSRT) of Iran for their PhD studies in Australia.

\section{Author details}

'School of Agriculture, Food and Wine, The University of Adelaide, Glen Osmond, SA 5005, Australia. ${ }^{2}$ Centre for Genetic Analysis and Applications and School of Environmental and Rural Science, University of New England Armidale, NSW 2351, Australia. ${ }^{3}$ IRTA. Centre de Recerca en Agrigenòmica CSIC-IRTA-UAB. Carretera de Cabrils Km2. 08348 Cabrils (Barcelona), Spain. ${ }^{4}$ CSIRO Livestock Industries, FD McMaster Laboratory, Chiswick, New England Highway, Armidale, NSW 2350, Australia. ${ }^{5}$ Faculty of Arts and Sciences, University of New England, Armidale, NSW 2351, Australia. ${ }^{6}$ Current Address: Faculty of Agriculture, University of Shahid Bahonar, Kerman, Iran. ${ }^{7}$ Current Address: Agricultural Research \& Development, Tasmanian Alkaloids, Westbury, TAS 7303, Australia.

\section{Authors' contributions}

IT and GR performed SSR genotyping, mapping analysis, and interpretation of the data. DG conducted RAPD, ISSR and SSR genotyping and initial mapping analysis. MM participated in the SSR genotyping and mapping analysis. MGW participated in the design of the study, collected samples and managed the mapping population. PWH and CMF participated in the design of the study and revised the manuscript critically. JPG participated in the design of the study and mapping analysis, and revised the manuscript critically. MS conceived of the study, participated in its design and coordination and revised the manuscript critically. SBW participated in the design of the study, performed SNP genotyping, analysed SSR genotyping data, completed final mapping analysis, conducted sequence and map alignments and drafted the manuscript. All authors have read and approved the final manuscript

Received: 17 June 2010 Accepted: 9 October 2010

Published: 9 October 2010

\section{References}

1. Ladizinsky G: On the origin of almond. Genet Resour Crop Evol 1999, 46:143-147.

2. Watkins R: Cherry, plum, peach, apricot and almond. In Evolution of crop plants. Edited by: Simmonds NW. London: Longman; 1979:242-247.

3. Ballester J, Bokovi R, Batlle I, Arús P, Vargas F, Vicente MC: Location of the self-incompatibility gene on the almond linkage map. Plant Breed 1998, 117:69-72.

4. Sánchez-Pérez R, Howad W, Dicenta F, Arús P, Martínez-Gómez P: Mapping major genes and quantitative trait loci controlling agronomic traits in almond. Plant Breed 2007, 126:310-318.

5. Channuntapipat C, Wirthensohn M, Ramesh SA, Batlle I, Arús P, Sedgley M, Collins G: Identification of incompatibility genotypes in almond (Prunus dulcis Mill.) using specific primers based on the introns of the $S$-alleles. Plant Breed 2003, 122:164-168.

6. Channuntapipat C, Sedgley M, Collins G: Sequences of the CDNAs and genomic DNAs encoding the $S 1,57,58$, and $S f$ alleles from almond, Prunus dulcis. Theor Appl Genet 2001, 103:1115-1122.

7. Sánchez-Pérez R, Howad W, Garcia-Mas J, Arús P, Martínez-Gómez P, Dicenta F: Molecular markers for kernel bitterness in almond. Tree Genet Genomes 2010, 6:237-245.

8. Ushijima K, Yamane H, Watari A, Kakehi E, Ikeda K, Hauck NR, lezzoni AF, Tao RT: The $S$ haplotype-specific F-box protein gene, SFB, is defective in self-compatible haplotypes of Prunus avium and P-mume. Plant J 2004, 39:573-586.

9. Martínez-Gómez P, Rubio M, Dicenta F, Gradziel TM: Resistance to plum pox virus (dideron isolate RB3.30) in a group of California almonds and transfer of resistance to peach. J Am Soc Hortic Sci 2004, 129:544-548.

10. Arús P, Gradziel T, Oliveira M, Tao R: Genomics of almond. In Genetics and Genomics of Rosaceae. Edited by: Folta KM, Gardiner SE. New York: SpringerVerlag; 2009:187-219.

11. Silva C, Garcia-Mas J, Sanchez AM, Arús P, Oliveira M: Looking into flowering time in almond (Prunus dulcis (Mill) D. A. Webb): the candidate gene approach. Theor Appl Genet 2005, 110:959-968.
12. Silva C, Sanchez AM, Oliveira MM: Isolation of full-length CDNAs with putative functions in almond (Prunus dulcis Mill.) flowering. Acta Hortic 2007, 738:675-682

13. Ballester J, Company RSI, Arús P, de Vicente MC: Genetic mapping of a major gene delaying blooming time in almond. Plant Breed 2001, 120:268-270.

14. International Peach Genome Initiative: Peach Genome V1.0. 2010 [http:// www.rosaceae.org/peach/genome].

15. Arús $P$, Messeguer $R$, Viruel M, Tobutt $K$, Dirlewanger $E$, Santi F, Quarta $R$, Ritter E: The European Prunus mapping project - progress in the almond linkage map. Euphytica 1994, 77:97-100.

16. Joobeur T, Periam N, Vicente MC, King GJ, Arús P: Development of a second generation linkage map for almond using RAPD and SSR markers. Genome 2000, 43:649-655.

17. Viruel MA, Messeguer R, de Vicente MC, Garcia-Mas J, Puigdomenech $P$, Vargas $F$, Arús P: A linkage map with RFLP and isozyme markers for almond. Theor Appl Genet 1995, 91:964-971.

18. Ballester J: Localitzacio I analisi de caracters d'interes agronomic de l'ametller Universitat Autonoma de Barcelona 1998.

19. Gregory D: The development of a genetic linkage map for almond based on molecular and agronomic markers. PhD thesis Adelaide: The University of Adelaide 2004.

20. Gregory D, Sedgley M, Wirthensohn M, Arús P, Kaiser B, Collins G: An integrated genetic linkage map for almond based on RAPD, ISSR, SSR and morphological markers. Acta Hortic 2005, 694:67-72.

21. Wu S-B, Tavassolian I, Rabiei G, Hunt P, Wirthensohn M, Gibson JP, Ford CM, Sedgley M: Mapping SNP-anchored genes using high-resolution melting analysis in almond. Mol Genet Genomics 2009, 282:273-281.

22. Joobeur T, Viruel MA, de Vicente MC, Jauregui B, Ballester J, Dettori MT, Verde I, Truco MJ, Messeguer R, Batlle I, et al: Construction of a saturated linkage map for Prunus using an almond $x$ peach $F_{2}$ progeny. Theor Appl Genet 1998, 97:1034-1041.

23. Dirlewanger $E$, Graziano E, Joobeur T, Garriga-Caldere F, Cosson $P$, Howad W, Arús P: Comparative mapping and marker-assisted selection in Rosaceae fruit crops. Proc Natl Acad Sci USA 2004, 101:9891-9896.

24. Howad W, Yamamoto T, Dirlewanger E, Testolin R, Cosson P, Cipriani G, Monforte AJ, Georgi L, Abbott AG, Arús P: Mapping with a few plants: Using selective mapping for microsatellite saturation of the Prunus reference map. Genetics 2005, 171:1305-1309.

25. Jauregui B, de Vicente MC, Messeguer R, Felipe A, Bonnet A, Salesses G, Arús P: A reciprocal translocation between 'Garfi' almond and 'Nemared' peach. Theor Appl Genet 2001, 102:1169-1176.

26. Foolad M, Arulsekar S, Becerra V, Bliss F: A genetic map of Prunus based on an interspecific cross between peach and almond. Theor Appl Genet 1995, 91:262-269.

27. Bliss FA, Arulsekar S, Foolad MR, Becerra V, Gillen AM, Warburton ML, Dandekar AM, Kocsisne GM, Mydin KK: An expanded genetic linkage map of Prunus based on an interspecific cross between almond and peach. Genome 2002, 45:520-529.

28. Dirlewanger E, Cosson P, Howad W, Capdeville G, Bosselut N, Claverie M, Voisin R, Poizat C, Lafargue B, Baron O, et al: Microsatellite genetic linkage maps of myrobalan plum and an almond-peach hybrid - location of root-knot nematode resistance genes. Theor Appl Genet 2004, 109:827-838.

29. Horn R, Lecouls AC, Callahan A, Dandekar A, Garay L, McCord P, Howad W, Chan H, Verde I, Main D, et al: Candidate gene database and transcript map for peach, a model species for fruit trees. Theor Appl Genet 2005, 110:1419-1428.

30. Lalli D, Decroocq V, Blenda A, Schurdi-Levraud V, Garay L, Le Gall O, Damsteegt $V$, Reighard G, Abbott A: Identification and mapping of resistance gene analogs (RGAs) in Prunus: a resistance map for Prunus. Theor Appl Genet 2005, 111:1504-1513.

31. Cabrera A, Kozik A, Howad W, Arús P, lezzoni AF, van der Knaap E: Development and bin mapping of a Rosaceae Conserved Ortholog Set (COS) of markers. BMC Genomics 2009, 29(10):562.

32. Wu S-B, Wirthensohn MG, Hunt $P$, Gibson JP, Sedgley M: High resolution melting analysis of almond SNPs derived from ESTs. Theor Appl Genet 2008, 118:1-14

33. Wu S-B, Franks TK, Hunt P, Wirthensohn MG, Gibson JP, Sedgley M: Discrimination of SNP genotypes associated with complex haplotypes by high resolution melting analysis in almond: implications for improved marker efficiencies. Mol Breed 2010, 25:351-357. 
34. Fan S, Bielenberg DG, Zhebentyayeva TN, Reighard GL, Okie WR, Holland D, Abbott AG: Mapping quantitative trait loci associated with chilling requirement, heat requirement and bloom date in peach (Prunus persica). New Phytol 2010, 185:917-930.

35. Campoy J, Martínez-Gómez P, Ruiz D, Rees J, Celton J: Developing microsatellite multiplex and megaplex PCR systems for high-throughput characterization of breeding progenies and linkage maps spanning the apricot (Prunus armeciaca L.) genome. Plant Mol Biol Report 2010, 28(4):560-568, 10.1007/s11105-11010-10186-11100.

36. Dirlewanger E, Cosson P, Boudehri K, Renaud C, Capdeville G, Tauzin Y, Laigret $F$, Moing A: Development of a second-generation genetic linkage map for peach [Prunus persica (L.) Batsch] and characterization of morphological traits affecting flower and fruit. Tree Genet Genomes 2006, 3:1-13.

37. Jung S, Staton M, Lee T, Blenda A, Svancara R, Abbott A, Main D: GDR (Genome Database for Rosaceae): integrated web-database for Rosaceae genomics and genetics data. Nucleic Acids Res 2008, 36:D1034-D1040.

38. Grattapaglia D, Sederoff R: Genetic linkage maps of Eucalyptus grandis and Eucalyptus urophylla using a pseudo-testcross: mapping strategy and RAPD markers. Genetics 1994, 137:1121

39. Maliepaard C, Alston FH, Van Arkel G, Brown LM, Chevreau E, Dunemann F, Evans KM, Gardiner S, Guilford P, Van Heusden AW: Aligning male and female linkage maps of apple (Malus pumila Mill.) using multi-allelic markers. Theor Appl Genet 1998, 97:60-73.

40. Wu S-B, Collins G, Sedgley M: A molecular linkage map of olive (Olea europaea L.) based on RAPD, microsatellite, and SCAR markers. Genome 2004, 47:26-35.

41. Van Ooijen JW, Voorrips RE: JoinMap ${ }^{\circledR}$ 3.0, Software for the calculation of genetic linikage maps. Wageningen, the Netherlands: Plant Research International 2001

42. Hanley S, Barker JHA, Van Ooijen JW, Aldam C, Harris SL, Ahman I, Larsson S, Karp A: A genetic linkage map of willow (Salix viminalis) based on AFLP and microsatellite markers. Theor Appl Genet 2002, 105:1087-1096.

43. Hanley SJ, Mallott MD, Karp A: Alignment of a Salix linkage map to the Populus genomic sequence reveals macrosynteny between willow and poplar genomes. Tree Genet Genomes 2007, 3:35-48.

44. Clarke J, Sargent D, Bošković R, Belaj A, Tobutt K: A cherry map from the inter-specific cross Prunus avium 'Napoleon' $\times P$. nipponica based on microsatellite, gene-specific and isoenzyme markers. Tree Genet Genomes 2009, 5:41-51.

45. Gupta P, Varshney R: The development and use of microsatellite markers for genetic analysis and plant breeding with emphasis on bread wheat. Euphytica 2000, 113:163-185.

46. Wünsch A: Cross-transferable polymorphic SSR loci in Prunus species. Sci Hortic 2009, 120:348-352.

47. Mnejja M, Garcia-Mas J, Howad W, Arús P: Development and transportability across Prunus species of 42 polymorphic almond microsatellites. Mol Ecol Notes 2005, 5:531-535.

48. Mnejja M, Garcia-Mas J, Audergon J, Arús P: Prunus microsatellite marker transferability across rosaceous crops. Tree Genet Genomes 2010, 6:689-700, DOl:10.1007/s11295-11010-10284-z.

49. Wirthensohn MG, Sedgley M: Almond breeding in Australia. Acta Hortic 2002, 591:245-248

50. Blenda A, Verde I, Georgi L, Reighard G, Forrest S, Muñoz-Torres M, Baird W, Abbott A: Construction of a genetic linkage map and identification of molecular markers in peach rootstocks for response to peach tree short life syndrome. Tree Genet Genomes 2007, 3:341-350.

51. Voorrips R: MapChart: software for the graphical presentation of linkage maps and QTLs. J Hered 2002, 93:77.

52. Decroocq V, Fave MG, Hagen L, Bordenave L, Decroocq S: Development and transferability of apricot and grape EST microsatellite markers across taxa. Theor App/ Genet 2003, 106:912-922.

53. Dirlewanger E, Cosson P, Tavaud M, Aranzana MJ, Poizat C, Zanetto A, Arús $P$, Laigret F: Development of microsatellite markers in peach [Prunus persica (L.) Batsch] and their use in genetic diversity analysis in peach and sweet cherry (Prunus avium L.). Theor Appl Genet 2002, 105:127-138.

54. Aranzana MJ, Garcia-Mas J, Carbo J, Arús P: Development and variability analysis of microsatellite markers in peach. Plant Breed 2002, 121:87-92.

55. Mnejja M, Garcia-Mas M, Howad W, Badenes ML, Arús P: Simple-sequence repeat (SSR) markers of Japanese plum (Prunus salicina Lindl.) are highly polymorphic and transferable to peach and almond. Mol Ecol Notes 2004, 4:163-166.

56. Clarke JB, Tobutt KR: Development and characterization of polymorphic microsatellites from Prunus avium'Napoleon'. Mol Ecol Notes 2003, 3:578-580.

57. Vaughan SP, Russell K: Characterization of novel microsatellites and development of multiplex PCR for large-scale population studies in wild cherry, Prunus avium. Mol Ecol Notes 2004, 4:429-431.

58. Yamamoto T, Mochida K, Imai T, Shi YZ, Ogiwara I, Hayashi T: Microsatellite markers in peach [Prunus persica (L.) Batsch] derived from an enriched genomic and cDNA libraries. Mol Ecol Notes 2002, 2:298-301.

59. Lopes $M$, Sefc K, Laimer M, Machado A: Identification of microsatellite loci in apricot. Mol Ecol Notes 2002, 2:24-26.

60. Downey SL, lezzoni AF: Polymorphic DNA markers in black cherry (Prunus serotina) are identified using sequences from sweet cherry, peach, and sour cherry. J Am Soc Hortic Sci 2000, 125:76-80.

61. Sosinski B, Gannavarapu M, Hager LD, Beck LE, King GJ, Ryder CD, Rajapakse S, Baird WW, Ballard RE, Abbott AG: Characterization of microsatellite markers in peach [Prunus persica (L.) Batsch]. Theor Appl Genet 2000, 101:421-428.

62. Wang Y, Georgi LL, Zhebentyayeva TN, Reighard GL, Scorza R, Abbott AG: High-throughput targeted SSR marker development in peach (Prunus persica). Genome 2002, 45:319-328.

63. Cantini $C$, lezzoni AF, Lamboy WF, Boritzki M, Struss D: DNA fingerprinting of tetraploid cherry germplasm using simple sequence repeats. J Am SoC Hortic Sci 2001, 126:205-209.

64. Struss D, Ahmad R, Southwick SM, Boritzki M: Analysis of sweet cherry (Prunus avium L.) cultivars using SSR and AFLP markers. J Am Soc Hortic Sci 2003, 128:904-909.

65. Testolin R, Messina R, Lain O, Marrazzo MT, Huang WG, Cipriani G: Microsatellites isolated in almond from an AC-repeat enriched library. Mol Ecol Notes 2004, 4:459-461.

66. Messina R, Lain O, Marrazzo MT, Cipriani G, Testolin R: New set of microsatellite loci isolated in apricot. Mol Ecol Notes 2004, 4:432-434.

67. Cipriani G, Lot G, Huang WG, Marrazzo MT, Peterlunger E, Testolin R: AC/GT and AG/CT microsatellite repeats in peach [Prunus persica (L) Batsch] isolation, characterisation and cross-species amplification in Prunus. Theor Appl Genet 1999, 99:65-72.

doi:10.1186/1471-2164-11-551

Cite this article as: Tavassolian et al:: Construction of an almond linkage map in an Australian population Nonpareil $\times$ Lauranne. BMC Genomics 2010 11:551.

\section{Submit your next manuscript to BioMed Central and take full advantage of:}

- Convenient online submission

- Thorough peer review

- No space constraints or color figure charges

- Immediate publication on acceptance

- Inclusion in PubMed, CAS, Scopus and Google Scholar

- Research which is freely available for redistribution

Submit your manuscript at www.biomedcentral.com/submit
C Biomed Central 